\title{
Pembangunan Singapura Sebagai Pusat Perdagangan di Asia Tenggara Pada Masa Gubernur Jenderal Raffles 1819-1820
}

\author{
Akhmad Syaekhu Rakhman ${ }^{1 *}$; Arief Hidayat ${ }^{2}$ \\ Universitas Indraprasta PGRI; a03rakhman@gmail.com \\ Universitas Indraprasta PGRI; ariefhidayat1610@gmail.com \\ *Korespondensi
}

Dikirim: 12-02-2021; Diterima: 26-05-2021; Diterbitkan: 30-06-2021

\begin{abstract}
Singapore in the period before Raffles' arrival was an area that was still covered in forests, mangroves, and mud. Raffles that who had renewed the agreement in 1785 with the Sultan of Johor then bought and built Singapore into a very strategic and bustling international port and trading city center. This study aims to explain Singapore's growth after Raffles' presence, explain Raffles' efforts in building Singapore, and explain Raffles' successful policy in building Singapore as a trading center. The research method used is the historical method through the stages, namely; heuristics, criticism, verification, interpretation and historiography. The results of this study provide information about the impact of the arrival of governor-general Raffles in the economy in Singapore, which can also affect progress in Indonesia and Southeast Asia.
\end{abstract}

Keyword: Raffles; Singapore; trade center

\begin{abstract}
Abstrak: Singapura pada masa sebelum kedatangan Raffles merupakan wilayah yang masih tertutup hutan, bakau, dan lumpur. Raffles yang telah memperbaharui persetujuan pada tahun 1785 dengan Sultan Johor kemudian membeli dan membangun Singapura menjadi pusat pelabuhan dan kota dagang internasional yang sangat strategis dan ramai. Penelitian ini bertujuan untuk menjelaskan pertumbuhan Singapura setelah kehadiran Raffles, menjelaskan upaya Raffles dalam membangun Singapore, dan menjelaskan kebijakan Raffles yang sukses membangun Singapura selaku pusat perdagangan. Metode penelitian yang digunakan adalah metode sejarah melalui tahapan yaitu; heuristik, kritik, verifikasi, interpretasi dan historiografi. Hasil penelitian ini memberikan sebuah informasi tentang dampak kedatangan gubernur jenderal Raffles dalam bidang perekonomian di Singapura yang dapat berpengaruh juga pada kemajuan di Indonesia dan Asia Tenggara.
\end{abstract}

Kata Kunci: Raffles; pusat perdagangan; Singapura

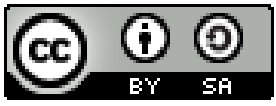

Jurnal Fajar Historia is licensed under a Creative Commons AttributionShareAlike 4.0 International License.

\section{Pendahuluan}

Perekonomian Asia Tenggara yang didukung oleh Singapura, Malaysia, dan Thailand belum lama ini telah berkembang pesat. Di samping itu dikenal dalam sejarah bahwa perekonomian di negara-negara itu telah berhasil dalam pembangunan di bidang intelektual. Singapura merupakan salah satu negara republik di Asia Tenggara dan anggota persemakmuran, yang mencakup sekelompok pulau dengan Singapura sebagai pulau paling banyak. Singapura merupakan negara di benua Asia yang perekonomian negaranya ditopang 
Pembangunan Singapura Selaku Pusat Perdagangan di Asia Tenggara Pada Masa Gubernur Jenderal Raffles (1819-1820)

oleh perdagangan. Singapura sebagai bagian dari kebudayaan Asia telah mengambil peran yang signifikan dalan pembangunan Asia dan menempatkan Singapura sebagai negara dengan pembangunan ekonomi dan kebudayaan yang diperhitungkan. Sebelumnya ada anggapan bahwa ada persoalan yang "salah" dengan kebudayan Asia, karena itu atensi mulai dicurahkan pada apa yang "benar" tentang kebudayaan ini. Tidak terdapat satupun dari kedua persoalan itu bermanfaat, namun jelas mengganggap kalau tempat Asia dalam "dunia ketiga" yang statis dan sedang merosot ini ditakdirkan oleh area dan budaya (Siryayasa, 2019: 88). Secara geografis Singapura berada di sebelah barat dan utara dengan selat Johor Malaysia, kemudian di sebelah timur dan selatan berbatasan dengan selat Singapura. Negara ini terletak 137 kilometer sebelah utara garis khatulistiwa. Posisi negara ini yang strategis dengan fasilitas infrastrukturnya yang berkembang pesat, dan kontras budayanya yang menawan, serta atraksi wisatanya segala kontribusi terhadap kesuksesannya, kemudian membuat negara menjadi daerah tujuan perdagangan (Julia, 2018: 2).

Sebelum Singapura menjadi sebuah negara, pada abad ke-14 pulau Singapura merupakan wilayah kerajaan Sriwijaya. Singapura pada masa sebelum kedatangan Raffles, ialah wilayah yang masih tertutup hutan, bakau, serta lumpur. Raffles yang memperbaharui persetujuan pada tahun 1785 dengan Sultan Johor kemudian membangun Singapura menjadi pusat pelabuhan dan kota dagang internasional. Pada tahun 1811, Sultan Husain Syah membangun istana di Kampong Glam, yang dipenuhi bakau yang susah dilewati. Orang menggunakan rute pesisir untuk berangkat ke Kampong Glam. Pada masa itu pulau Singapura merupakan bagian dari Kesultanan Johor (Melayu), yang setelah itu dibeli oleh Raffles (Bastin, 2011: 13). Raffles mendatangi Singapura pada tanggal 29 Januari 1819 dan bermaksud menduduki Johor, tetapi sudah didahului oleh Belanda. Raffles bermaksud menguasai Pulau Karimun, tetapi dianggap tidak cocok untuk dijadikan pelabuhan. Raffles kemudian kembali Kekepulauan Riau yang masih dikuasai oleh Sultan Johor, dari Sultan Johor kemudian Raffles membeli Pulau Singapura. Belanda menguasai hampir seluruh daerah kekuasaan Sultan Johor, lewat suatu perjanjian. Tetapi, Sultan Johor masih memegang hak atas tanah di daerah yang dibeli oleh Raffles (Magandaralam, 1987: 19).

Raffles memiliki rencana jangka panjang tentang Singapura. Impian Raffles untuk memajukan Singapura menjadi kota yang maju dengan adanya pelabuhan dan menjadi tempat berkumpulnya kapal-kapal dari Eropa. Singapura pada masa kepemimpinan Raffles tumbuh menjadi kota pelabuhan yang ramai. Pelabuhan Singapura tumbuh dan berkembang menjadi pusat perkapalan di Asia dan Eropa. Semenjak dibangunnya pelabuhan ini banyak kapal-kapal asing yang singgah. Pintu masuk ke daerah Singapura lewat sungai Singapura (Singapore river) yang sangat strategis sehingga Raffles memutuskan membangun pelabuhan di Sungai Singapura yang dahulunya masih berbentuk rawa menjadi pusat pelabuhan luas (Hannigan, 2012: 105). Pada tahun 1832 Singapura menjadi pusat pemerintahan Straits Settlements (wilayah pemukiman teluk) untuk daerah Penang, Malaka dan Singapura. Pembukan terusan Suez pada tahun 1869 dan penemuan telegraf dan kapal uap semakin memperbesar peran Singapura sebagai pusat perdagangan yang terus tumbuh dan meningkat antara Timur dan Barat. 
Pembangunan Singapura Selaku Pusat Perdagangan di Asia Tenggara Pada Masa Gubernur Jenderal Raffles (1819-1820)

Penelitian sebelumnya yang pernah dilakukan oleh peneliti lainnya tentang Singapura ada yang berupa buku ataupun hasil riset. Namun sebagian besar dari mereka mangulas tentang kondisi Singapura ketika mulai masuk ke dalam wujud strait settlement Inggris hingga pada awal abad ke-21. Phillippe Regnier (1991) menulis buku yang bertajuk "Singapura City State in South- East Asia". Fokus penyusunan terletak pada aspek politik serta ekonomi Singapura tahun 1960 sampai terbentuknya ASEAN dan peranan Singapura dalam ASEAN. Pada bab I sekilas memaparkan tentang sejarah maritim semenjak kerajaan Sriwijaya serta berkembangnya Singapura menjadi pelabuhan dagang pada masa Raffles. Penelitian lainnya dari Iman Chaerullah (2011) dengan judul "Kegiatan Pelayaran serta Perdagangan Warga Muslim Melayu Singapura tahun 1800-1824”. Fokus penelitian ini berisi tentang posisi Singapura selaku daerah perniagaan didukung oleh kenaikan volume dagang serta lintas kapal yang ramai di selat Malaka selaku jalan penghubung perdagangan Asia Tenggara dengan daerah Samudera Hindia serta laut Tiongkok Selatan. Ibrahim Zuraidah (1953) menulis buku dengan judul "Orang Islam di Singapura". Fokus penulisannya berisi tentang sosial masyarakat Singapura pada abad ke19 dan sekilas menerangkan etnis-etnis dalam warga Islam Singapura.

Keberbedaan penelitian ini dengan beberapa penelitian di atas yakni pada aspek sejarah pembentukan Singapura sebagai pusat perdagangan dunia pada masa kekuasaan Raffles. Oleh karena itu urgensi penelitian ini dapat dilihat pada aspek kesejarahan terbentuknya Singapura sebagai pusat perdagangan dunia. Tujuan penelitian ini hendak menjelaskan pertumbuhan Singapura setelah kehadiran Raffles, upaya Raffles dalam membangun Singapore, dan kebijakan Raffles yang sukses membangun Singapura selaku pusat perdagangan. Secara lebih luas dijelaskan peran dan kontribusi Raffles dalam membangun Singapura sehingga diakui sebagai pusat perdagangan dunia dengan pelabuhan yang ramai.

\section{Metode Penelitian}

Penelitian ini menggunakan metode sejarah. Metode sejarah digunakan untuk menjelaskan tentang pembangunan Singapura selaku pusat perdagangan pada masa Gubernur Jenderal Raffles (1819-1820). Tahap-tahap dalam tata cara metode sejarah ini dilakuakan melalui tahapan heuristik (pengumpulan informasi), kritik, interpretasi, dan historiografi (penyusunan sejarah) (Sjamsuddin, 2007). Proses heuristik dilakukan dimana data-data dikumpulkan dari buku dan jurnal. Pengumpulan data-data ini diperoleh lewat riset kepustakaan yang relevan dengan riset yang sedang dilakukan. Setelah itu proses selanjutnya dilakukan kritik untuk mendapatkan fakta yang akurat dan dapat dipertanggung jawabkan. Tahap berikutnya adalah interpretasi. Interpretasi merupakan tahapan dimana data-data yang telah diverifikasi sehingga menjadi fakta sejarah kemudian dianalisis untuk memperoleh rangkaian peristiwa yang dihubungkan satu sama lain sehingga jadi satu kesatuan yang utuh serta logis. Tahap selanjutnya ialah penyusunan sejarah dimana dalam tahapan terakhir ini kerangka sejarah sudah terbentuk, selanjutnya disusun jadi suatu historiografi yang lengkap (Gottschalk, 1985: 57).

\section{Hasil Penelitian}


Pembangunan Singapura Selaku Pusat Perdagangan di Asia Tenggara Pada Masa Gubernur Jenderal Raffles (1819-1820)

\section{Kota Singapura dalam Catatan Sejarah}

Kota Singapura didirikan di kedua tepi teluk yang lebih dikenal dengan nama Sungai Singapura. Di salah satu tepinya terdapat banyak gudang, kantor, toko para pedagang dan saudagar, serta tempat tinggal penduduk, pasar dan lain-lain. Di daerah Commercial Square berdiri bangunan-bangunan indah yang digunakan sebagai kantor, toko dan tempat tinggal. Sungai yang mengalir di dekat permukiman selalu menyuguhkan pemandangan menarik. Kapal-kapal penduduk asli yang hilir mudik, berisikan buah-buahan, sayuran, dan ternak beberapa sampan kosong milik penduduk lokal yang tersusun rapi an siap disewa atau sedang dipakai melayani para kapten kapal yang tidak ingin anak buahnya bekerja dibawah sengatan matahari tropis. Banyak perahu penduduk lokal tengah menunggu atau mengantarkan kargo beragam hasil bumi pulau- pulau subur di sekitar Singapura (Bastin, 2011:10).

Daerah Singapura pertama kali disebut dalam catatan bangsa China pada abad ke-3 M, yaitu, Singapura sebagai "Pu-luo-chung" (pulau di ujung semenanjung). Daerah ini merupakan salah satu negara pulau di Asia Tenggara yang terletak di selatan garis khatulistiwa, di lepas pantai selatan Semenanjung Melayu terpisah dari daratan oleh selat Johor, di akhir bagian selatan dari Selat Malaka (Bastin, 2011:11). Kota Singapura berada di pulau dengan nama yang sama terletak pada ujung daratan di sebelah barat. Singapura sebelum datangnya Raffles masih berupa hutan bakau yang menutupi seluruh pulau, belum ada rumah satu pun di pulau Singapura,dan ditutupi hutan rimba, pantainya dipenuhi pohon bakau dan pepaya. Setelah dihuni oleh manusia, hutan rimba berangsur-angsur hilang. Satu-satunya daerah hutan yang masih tersisah adalah Cagar Alam Bukit Timah. Daerah ini banyak dikunjungi orang untuk menikmati pepohonan, tanaman menjalar, semak belukar, dan juga menikmati binatang yang hidup di Cagar Alam tersebut (Magandaralam, 1987:15). Sungai Singapura memang tidak sebesar sungai Amazon, Missisippi atau Mekong, itupun tidak menghubungkan daerah pedalaman yang luas dengan pantai dan panjangnya yang dapat dilayari maksimum hanya sekitar tiga kilometer. Kedalamannya yang dangkal dan luasnya yang sempit tidak dapat dilintasi oleh kapal-kapal besar namun, sangat penting bagi Singapura. Karena itulah, sungai Singapura tidak dapat dilintasi oleh kapal-kapal besar, dan hanya dapat dilewati oleh kapal kecil (Sasrawan, 2013: 30).

Singapura adalah sebuah negara kota berbentuk pulau yang berada di ujung semenanjung Malaya dan berbatasan langsung dengan negara Malaysia. Letak geografisnya terhubung langsung dengan Selat Malaka, yang memiliki nilai strategis secara ekonomis maupun geopolitik (Amin, 2018: 1). Negara Singapura yang terletak di ujung paling selatan dari Semenanjung Malaka dibangun oleh Sir Stamford Rafles. Singapura merupakan suatu wilayah di Asia Tenggara yang terletak di lepas pantai selatan Semenanjung Malaya, posisinya berada di selatan dari Selat Malaka. Penduduk pribumi Singapura adalah orang Melayu yang sebagian besar terdiri dari Orang Laut. Kota ini mudah dikenali karena terdapat sebuah bukit indah di belakangnya yang hanya sebagian ditumbuhi pohon (Mangandalaram, 1987: 33).

\section{Singapura Pada Masa Kerajaan}


Pembangunan Singapura Selaku Pusat Perdagangan di Asia Tenggara Pada Masa Gubernur Jenderal Raffles (1819-1820)

Singapura sebelumnya bernama Tumasik/Temasek yang dalam bahasa Jawa kuno berarti Kota Laut. Referensi lain menyebutkan berarti menyerupai laut. Nama Tumasik disebut dalam Sumpah Palapa, sebagai daerah yang akan ditaklukkan dan dimasukkan ke dalam wilayah administrasi Majapahit. Awalnya Singapura/Tumasik adalah Pos Luar dari Kerajaan Besar Sriwjaya (Saefullah, 2016: 427). Saat itu Sriwijaya memiliki wilayah kekuasaan hingga Semenanjung Malaya (Malaysia), Kamboja, Thailand, Filipina dan Vietnam. Tidak mengherankan jika Sriwijaya dan Majapahit menjadi referensi Nusantara oleh para pejuang pra kemerdekaan (Kennedy, 1962: 15).

Selat Malaka telah dikuasai oleh kesultanan di Semenanjung Malaya sejak abad ke-15. Sejak abad ke-15, intensitas kedatangan para pedagang internasional dalam jumlah besar seperti Arab, Persia, Turki, Cina, India, dan Jepang. Hal ini menyebabkan para pedagang Melayu berperan penting dalam perdagangan regional. Kapal-kapal perniagaan Melayu bermuatan besar mendominasi jalur perdagangan regional sebagai perantara pembelian komoditi dagang dari kawasan Timur Indonesia. Pada akhir abad ke-15 terdapat seorang utusan Singapura yang datang ke Malaka untuk mengakui kedaulatan Sultan Malaka. Abad ke-15 M, Tumasik berada di bawah kekuasaan Ayutthaya-Thailand, dan selanjutnya dikuasai Kesultanan Malaka sampai pendudukan Portugis 1511 M. Sejak abad ke-15 hingga abad ke-17 terdapat sejumlah besar golongan pedagang Melayu di kota-kota niaga Malaka, Patani, Ayudhaya, Johor, Aceh, Brunei, Makassar, dan kota-kota pelabuhan di Jawa. Mereka membentuk jaringan perdagangan yang saling berhubungan antarkota niaga dengan bahasa Melayu sebagai bahasa perdagangan. Orientasi perdagangan Melayu yang berpusat di kota-kota niaga mendominasi perdagangan dan perkapalan antarpulau, di samping bahasa Melayu menjadi bahasa niaga di kota-kota niaga Asia Tenggara (Syah, 1985: 12).

Singapura yang terletak di perairan Malaka masih belum banyak dihuni orang Melayu pada abad ke-18. Negara ini berubah pada awal abad ke-19 ketika Raffles datang dan menegakkan kekuasaan Inggris. Sebagai pelabuhan bebas, Singapura menjadi pusat perdagangan dan perkapalan bagi pulau-pulau disekitarnya. Keberhasilan itu didukung penyerahan kembali Bengkulu pada tahun 1816, setelah pemerintah Inggris gagal membujuk seorang bangsawan Johor untuk megizinkan permukiman Kompeni Inggris di Hindia Timur. Ketika itu, Johor berada dibawah pengaruh Kekuasaan Belanda. Kolonial Belanda menyerahkan Johor ke Inggris tahun 1824 setelah beberapa kali terjadi perjanjian (Dobbs, 2002: 19).

\section{Kedatangan Raffles di Singapura}

Sungai Singapura dimanfaatkan sebagai pusat perdagangan yang berkembang di tepi sungai. Kehadiran bangsa-bangsa Eropa sejak abad ke-16 dengan tujuan sebagai upaya kolonialisasi dan memonopoli perdagangan, menutup peran perdagangan masyarakat dan kotakota niaga di Asia Tenggara. Kolonialisasi Inggris di Singapura menimbulkan respon yang mengarah kepada sikap reaksi pertentangan terhadap dominasi Inggris. Bentuk pertentangan ini diimplementasikan dalam aktivitas pembajakan yang dijalankan oleh Orang Laut terhadap kapal-kapal dagang yang melintas di sekitar selat (Chaerullah, 2011: 7). 
Pembangunan Singapura Selaku Pusat Perdagangan di Asia Tenggara Pada Masa Gubernur Jenderal Raffles (1819-1820)

Pada abad ke-17 hingga abad ke-19, Belanda dan Inggris merupakan dua kekuatan Eropa yang berpengaruh dalam persaingan hegemoni. Organisasi dagang Belanda Vereenigde Oostindische Compagnie (VOC) mengukuhkan dominasinya dengan mengalahkan Portugis di Malaka. Dominasi Belanda dalam monopoli perdagangan rempah-rempah terjadi dari perjanjian dagang dengan raja-raja lokal di kepulauan Timur Indonesia. Organisasi dagang Inggris (EIC) mulai berkembang dan berpengaruh di Hindia Timur pada abad ke-17. Keberadaan pos perdagangan di sungai Singapura telah membuka hubungan perdagangan dengan wilayah-wilayah di Samudera Hindia, Cina, Jepang, Siam, Burma serta Nusantara (Hannigan, 2012: 25).

Raffles, dari Kalkuta bergegas ke pulau Penang dan mengirimkan ekspedisi untuk mencari tempat yang sesuai untuk mendirikan satu pusat perdagangan dan pelabuhan untuk pelayaran ke Cina. Raffles berencana menduduki Johor, tetapi Belanda telah mendahului, dan telah memperbaharui perjanjian kepulauan Karimun di Selat Malaka, tapi ternyata kurang cocok untuk pusat perdagangan. Raffles melihat ke pulau Riau, yang merupakan bagian dari dari kesultanan Johor. Raffles kemudian membeli pulau Singapura dari Sultan Johor. Raffles kemudian berinisiatif untuk mencari alternatif pelabuhan laut lainnya. Memudahkan akses perdagangan dan untuk dijadikan pangkalan laut kolonial Inggris kala itu (Bastin, 2011: 25). Masa penting lain dalam sejarah Singapura adalah saat abad ke-18, ketika Singapura modern didirikan. Selain itu para pedagang Inggris juga memerlukan sebuah tempat strategis untuk mengisi perbekalan dan melindungi armada niaga kerajaan yang sedang berkembang pesat, serta untuk menahan gerak maju Belanda di kawasan ini (Hannigan, 2012: 40).

Pada abad ke-18 Inggris mengadakan perjalanan ke Malaka. Inggris semakin memantapkan kekuasaannya di Jazirah Malaya. Inggris merebut Malaka dari tangan Belanda, kemudian ditukar dengan Bengkulu yang semula dikuasai oleh Inggris. Tujuan kedua negara kolonial tersebut tidak lain adalah untuk menyatukan wilayah kekuasaan mereka yang sudah terlebih dahulu berada dalam kekuasaannya. Dua tahun kemudian wilayah Pinang, Malaka, dan Singapura dihimpun dalam satu wilayah kekuasaan Inggris yang dikenal dengan nama Straits Settlements (Wilayah Permukiman Selat Malaka). Setelah jajahan Belanda jatuh ke tangan Inggris, Raffles diangkat menjadi Letnan Gubernur Jenderal yang diserahkan untuk bertugas mengurus Pulau Jawa, Madura, Palembang, Banjarmasin, dan Nusa Tenggara (Chaerullah, 2011: 13).

Raffles memimpin ekspedisi ke Malaka tidak menunggu sampai menerima izin Britania untuk mendarat, tapi dengan mengklaim wilayah itu sebagai milik Belanda berdasarkan perjanjian. Sementara itu orang Britania di Pulau Penang ikut campur tangan dalam suatu perang suksesi di Aceh dan mendukung klaim seorang pedagang kaya di kota itu atas takhta kesultanan. Raffles memutuskan bahwa sudah waktunya bertindak tegas, jangan sampai kalah dengan pertempuran diplomatik di seluruh wilayah tersebut. Raffles bergegas ke Kalkuta dan menjelaskan kepada Gubernur Jenderal Lord Moira akan perlunya mempertahankan tempat di selat Malaka demi keamanan perniagaan Britania dari India ke Cina. Raffles menjelaskan bahwa pemerintahan Belanda bermaksud memulihkan sistem monopoli dan menutup perairan di timur itu dari semua bangsa yang lain. 
Pembangunan Singapura Selaku Pusat Perdagangan di Asia Tenggara Pada Masa Gubernur Jenderal Raffles (1819-1820)

Inggris mengisi bagian penting berikutnya dalam kisah Singapura ini. Selama abad ke18, mereka melihat perlunya sebuah "rumah singgah" strategis untuk memperbaiki, mengisi bahan makanan, dan melindungi armada kerajaan mereka yang semakin besar, serta untuk menahan kemajuan bangsa Belanda di wilayah ini. Dengan latar belakang politik seperti inilah Sir Stamford Raffles mendirikan Singapura atau Singapore, sebagai tempat perdagangan. Kebijakan perdagangan bebas berhasil menarik para pedagang dari seluruh penjuru Asia, bahkan dari negeri-negeri jauh seperti Amerika Serikat dan Timur Tengah (Hannigan, 2012: $35)$.

Pada tahun 1771 Sultan Kedah (yang menguasai Penang) berhubungan dengan Francis Light yang bersedia menyerahkan pulau Penang kepada Inggris dengan syarat Inggris melindungi Kedah dari ancaman Sultan Selangor. Raffles sebelum mendatangi Singapura pada tahun 1782, melihat wilayah Buleleng dikuasai oleh salah satu raja asal Karangasem. Selain Buleleng dan Karangasem, dia juga menguasai Jembrana dan Raffles berniat membuat pusat perdagangan di Buleleng. Pada 1783, Karangasem merebut wilayah Buleleng dari Kerajaan Mengwi dan Raffles membatalkan niat untuk menjadikan sebuah pusat perdagangan di Buleleng. Raffles ingin bekerja sama dengan Gde Karang untuk membangun kota pelabuhan dengan nama Singapura. Raffles tergiur melihat keramaian pelabuhan Buleleng. Pelabuhan itu sangat strategis, letaknya di antara kepulauan Nusantara. Apalagi Buleleng kala itu sedang berjaya dari hasil monopoli candu dan penjualan budak. Gde Karang rupanya tertarik dengan rencana Raffles (Hannigan, 2012: 37).

Raffles bermaksud menduduki Johor, tetapi ia sudah didahului oleh Belanda yang memperbaharui perjanjian tahun 1785 dengan Sultan Johor. Raffles kemudian mengincar Pulau Karimun tetapi, dianggap tidak sesuai dan kembali ke Kepulauan Riau yang dikuasai oleh Sultan Johor dan dari Sultan Johor Raffles membeli Pulau Singapura. Ketika Raffles berlabuh di Singapura, terdapat 150 orang Melayu yang tinggal dalam 100 pondok kecil di pinggir Sungai Singapura. Sultan Temenggong tinggal di dalam rumah yang besar. Terdapat pula beberapa pondok Orang Laut di ujung Kampong Glam. Sebagian besar Orang Laut bertempat tinggal di dalam perahu sampan (Kennedy, 1962: 17).

Raffles kembali ke Bengkulu pada tahun 1810 segera setelah penandatanganan perjanjian dengan Sultan Johor dan menugaskan Mayor William Farquhar untuk memimpin permukiman baru dengan jabatan Residen, dengan beberapa meriam dan 1 resimen infantri tentara India. Membangun sebuah pelabuhan niaga dari nol adalah sebuah tantangan yang berat. Farquhar hanya menerima dana yang tidak banyak, sementara dilarang untuk memungut pajak pelabuhan untuk meningkatkan pendapatan lantara Raffles sudah memutuskan bahwa Singapura akan menjadi pelabuhan bebas (Bastin, 2011: 14).

Raffles ditugaskan sebagai utusan Gubernur Jendral di Lautan Timur, dan pada tahun 1811 Raffles ditunjuk sebagai pimpinan dan Malaka sebagai basis ekspedisi ketika pengambilalihan Jawa ke Inggris. Selanjutnya Raffles menjabat sebagai Letnan Gubernur Inggris di Jawa selama lima tahun (1811-1816). Sebelum Raffles datang ke Singapura, Raffles mendatangi Jawa. Namun Raffles semakin giat dalam usahanya untuk membuat sejumlah rencana pasti dan 
Pembangunan Singapura Selaku Pusat Perdagangan di Asia Tenggara Pada Masa Gubernur Jenderal Raffles (1819-1820)

menyingkirkan Belanda dari Palembang. Pada Maret 1811 Raffles menyebrang selat Malaka dan menandatangani sebuah perjanjian dengan Sultan Badaruddin. Perjanjian tersebut penuh dengan kata-kata yang lebih kasar bagi Belanda. Perjanjian tersebut menyatakan bahwa sesudah penandatangan perjanjian itu istana Palembang akan membatalkan seluruh perjanjian dan kesepakatan dengan Belanda, mendeklarasikan kemerdekaan, dan kemudian menyetujui tidak akan pernah menerima kembali kedatangan residen seperti itu atau agen kekuasaan asing apapun kecuali Inggris (Vlekke, 2008: 28).

Pada tahun 1814, dua bulan setelah di Bengkulu, Raffles mengirimkan satu detasemen kecil pasukan keujung selatan Sumatra untuk mendudukan satu desa di pantai selat Sunda. Belanda mengibarkan bendera mereka berdampingan dengan bendera Britania, dan secara resmi memprotes Kalkuta. Atas perintah Kalkuta, Raffles meninggalkan posisi yang didudukinnya itu. Raffles protes keras, tapi sia-sia. Dalam surat-suratnya ke Kalkuta dan London, Raffles berdalih bahwa pemerintahan Britania tidak boleh mengizinkan kesatuan politik Sumatera dipecah-pecah. Seluruh pulau itu, harus diletakkan di bawah perlindungan Britania. Raffles tidak memperoleh dukungan untuk gagasannya tersebut, tetapi Raffles tidak menyerah. Pada perjanjian 1814 tampaknya tidak jelas mengenai pulau Belitung yang memproduksi Timah. Tidak ada tentara atau perwira Britania di pulau itu. Raffles mendorong teman sejawatnya di pulau Penang menunda penyerahan Malaka dan mengirimkan satu ekspedisi ke Kalimantan bagian barat untuk memantapkan klaim atas wilayah itu (Mangandalaram, 1987: 45).

Thomas Stamford Raffles merupakan sosok yang dianggap sebagai tokoh pendiri Singapura modern. Pada tahun 1818, Raffles datang ke Hindia Belanda sebagai Gubernur Hindia Belanda (kini Indonesia) untuk membuka jalur perdagangan dan mencari jalur pelabuhan laut yang stategis. Namum, ternyata kekayaan alam dan letak Bengkulu sebagai pelabuhan dan jalur perdagangan tersebut rupanya tidak terlalu menarik minat dan belum membuat Raffles merasa puas. Pada 6 Februari 1819 Thomas Stamford Raffles menemukan Singapura sebagai pelabuhan dagang Inggris. Seperti dilansir On This Day, Raffles merupakan negarawan Inggris dan pendiri Kota Singapura yang terletak di Asia Tenggara (Hannigan, 2012: 26).

Memasuki wilayah Singapura melalui sungai tersebut, Raffles menganggap wilayah tersebut strategis sehingga ia memutuskan membangun pulau yang mayoritas wilayahnya saat itu masih berupa rawa menjadi sebuah pusat pelabuhan bebas. Raffles memulai seluruh pembangunan Singapura sebagai pusat niaga dari sisi sungai tersebut. Pada tahun kedatangannya 1819, ia membangun gedung pemerintahan di sisi utara sungai. Sekitar empat tahun berselang, di sisi sungai tersebut dibangun Boat Quay yang menjadi kantor, gudang, dan dermaga bagi para pelaut dari sejumlah wilayah, seperti Tiongkok, India, Melayu, hingga Bugis yang berdagang di Singapura (Mangandalaram, 1987: 31). Sementara niat Raffles mendirikan pelabuhan dan kota di pulau Singapura dan di Bali tidak terlaksana. Pada 28 Januari 1819, Raffles mendarat di pulau utama di Singapura. Dari kunjungan itu akhirnya dia baru berhasil mendirikan kota kecil impiannya bernama Singapura (Idris, 1997: 71). Raffles menemukan 
Pembangunan Singapura Selaku Pusat Perdagangan di Asia Tenggara Pada Masa Gubernur Jenderal Raffles (1819-1820)

sebuah desa nelayan milik Sultan Johor, desa tersebut merupakan pusat pemerintahan kerajaan Melayu (Trocki, 1979: 28).

Dahulu pusat kota dan sebagian besar barang diperdagangkan di tangani oleh bank-bank di kota tersebut. Singapura mengalami kemajuan yang pesat dari segi ekonomi yang ditandai dengan masuknya industrialisasi, maupun dari segi sosial masyarakatnya yang ditandai oleh masuknya para imigran dari berbagai negara; Cina, India serta wilayah Nusantara; Bugis, Minangkabau dan Bawean, yang dipekerjakan dan menambah populasi masyarakat. Singapura telah tumbuh menjadi kota pelabuhan sejak 1819, dan terus berkembang sampai pendirian Singapura modern sampai saat ini. Selama jangka waktu tersebut menjadi tanda bahwa sungai dalam perkembangan sejarah telah menjelma menjadi kota modern yang dikenal sebagai Singapura (Hannigan, 2012: 37).

Pada tahun 1819 ketika Raffles mengusulkan kepada Pemerintah Inggris untuk membeli daerah Singapura dari Sultan Johor sebagai pelabuhan. Raffles sadar bahwa yang dibutuhkan Inggris di masa depan adalah kota pelabuhan dan pusat dagang di Timur Jauh. Singapura dinilai sebagai daerah yang sangat cocok untuk dijadikan tempat itu. Dalam hal ini Singapura telah melebihi harapan yang paling optimis sekalipun. Ketika baru ditemukan pada 1819, pulau ini hanya dihuni oleh ratussan nelayan Melayu yang merangkap sebagai perompak. Sebelum 1819, baik pulau ataupun pelabuhannya tidak diketahui banyak orang. Kapal- kapal Eropa tidak hanya jarang melewati tempat ini, tetapi juga menjauhinya (Bastin, 2011: 21).

Singapura telah tumbuh menjadi emperium yang penting dan Britania bermaksud tetap memiliki kota tersebut dan wilayah di sekitarnya. Inggris tetap mengakui klaim Belanda atas wilayah yang sama, karena itu pemerintah Britania mengusulkan tukar menukar Semenajung Malaya dengan daerah Bengkulu, klaim Britania atas Belitung dan hak-hak yang diperoleh Raffles di Aceh tahun 1819. Britania juga berjanji tidak akan lagi campur tangan di Sumatra atau pulau-pulau di kepulauan Indonesia. Orang Belanda juga berjanji menghormati kemerdekaan Aceh, tapi sekaligus bertekad melindungi pelayaran di sekitar ujung Sumatra dari perompak- perompak Aceh, dua janji yang sulit dipegang pada saat yang sama (Vlekke, 2008: 27).

Awalnya Mayor William Farquhar tidak menerima kebijakan baru Raffles tersebut. Raffles memecat dan meminta Farquhar pergi dari Singapura. Farquhar menolak pemecatan itu dan belakangan menuntut Raffles atas tindakannya. Konflik ini berlanjut hingga kepergian Raffles pada Oktober 1823 dan Farquhar baru pergi meninggalkan kota yang dia bangun sepenuhnya dari nol tersebut pada 28 Desember 1823. Kerajaan Melayu mengadakan perundingan dan akhirnya Sultan memberikan lahan tersebut kepada East India Company pada 1824, pelabuhan bebas kontan, desa nelayan yang semula berbukit-bukit dan penuh pohon buah itu berubah menjadi pusat bisnis Internasional. Dengan penandatanganan Perjanjian Anglo Belanda pada tahun 1824, Inggris dan Belanda menyepakati bidang pengaruh masing-masing dengan menggambar garis imajiner melalui Selat Malaka. Wilayah di selatan dan barat garis ini berada di bawah pengaruh Belanda sementara daerah ke utara dan timur berada di bawah pengaruh Inggris. Demarkasi ini meninggalkan pemukiman Malaka dan Bencoolen di sisi yang 
Pembangunan Singapura Selaku Pusat Perdagangan di Asia Tenggara Pada Masa Gubernur Jenderal Raffles (1819-1820)

salah. Britanian dan Holland memutuskan untuk melakukan pertukaran. Malaka kemudian menjadi ketergantungan Governour General of India dari 1824 hingga 1826 (Trocki, 1979: 12).

Di tahun 1824, hanya lima tahun setelah pendirian Singapura modern, populasi penduduk tumbuh pesat dari hanya 150 menjadi 10.000 orang. Perjanjian 1824 mengakhiri kekuasaan Britania atas Bengkulu dimana Raffles kemudian kembali ke Inggris. Dia berhasil mendirikan pemerintahan Britania di Kepulauan Indonesia, kota Singapura yang Raffles dirikan menjadi imperium utama di Asia bagian selatan. Perairan sungai menjadi pusat aktivitas pulau ini. Kapal-kapal bercat berwarna-warni yang disebut cahaya, mulai dari beberapa ton hingga lebih dari 150 ton, memenuhi aliran air sungai. Mereka membawa barang-barang perdagangan yang berharga dari kapal di pelabuhan luar ke dermaga di sepanjang sungai, kadang-kadang membentuk selimut tak tertembus maya di perairannya. Sebuah komunitas penduduk yang terdiri dari orang-orang yang lebih ringan memuat sejumlah barang yang tampaknya tak berujung yang terikat untuk kawasan Asia Tenggara ke dalam pemantik India dan Cina ini, tongkang dan twakow (Dobbs, 2002: 33).

Berdirinya Singapura kini dinyatakan sebagai prestasi terbesar Raffles (meski pada kenyataannya Raffles hanya menghabiskan kejayaan dengan Wiliam Farquhar yang ada disana selama masa terakhirnya sebagai residen Inggris pertama di Singapore). Perubahan yang dialami oleh Singapura dari abad ke abad dengan berbagai hal dan kondisi yang berbeda, membuat Singapura tumbuh sebagai salah satu wilayah yang sangat maju dalam jalur perniagaan di sekitar Selat Malaka dengan perdagangan sebagai mata pencaharian utama bagi masyarakat Singapura. Hal tersebut dapat dilihat dari sisi historisnya hingga abad ke-19, ketika Singapura sebagai sebuah pusat perdagangan Inggris di Asia Tenggara (Mangandalaram, 1987: 25).

\section{Raffles Membangun Singapura}

Ikatan dagang antara para pedagang Asia Tenggara serta para pedagang internasional, Tiongkok, Arab, serta India, berlangsung semenjak abad awal masehi. Para pedagang asing singgah buat memperdagangkan beberapa barang dari negara asal ataupun dari negeri-negeri yang mereka singgahi, sebaliknya para pedagang pribumi memperdagangkan hasil bumi Asia Tenggara. Pulau-pulau di kawasan Semenanjung Malaya serta Nusantara merupakan pusat penghasil kekayaan bumi, sebaliknya pulau-pulau di kawasan Timur Indonesia merupakan pusat penghasil bumbu yang diperlukan oleh para pedagang asing.

Pada akhir abad ke-14, perdagangan Singapura mengalami kemunduran yang disebabkan oleh beberapa aspek sepert; serangan kerajaan Siam, serangan bajak laut, dan keberadaan kesultanan Malaka selaku emporium perdagangan terbanyak serta pusat penyebaran Islam di Asia Tenggara. Singapura merupakan negeri yang sangat maju di antara negara-negara yang kecil di dunia (Chaerullah, 2011: 5). Letak geografis Singapura selaku daerah pesisir mendesak kegiatan kemaritiman penduduk Singapura dengan profesi nelayan serta pedagang. Posisi Singapura selaku daerah perniagaan didukung oleh kenaikan volume dagang serta lalu-lintas kapal yang ramai di Selat Malaka selaku jalan penghubung perdagangan Asia Tenggara dengan daerah Samudera Hindia serta Laut Tiongkok Selatan. Kemajuan perdagangan kerajaan 
Pembangunan Singapura Selaku Pusat Perdagangan di Asia Tenggara Pada Masa Gubernur Jenderal Raffles (1819-1820)

Melayu, semenjak kerajaan Sriwijaya hingga kesultanan Johor, selaku aspek penggerak pertumbuhan berbagai daerah kekuasaan mereka, teutama Singapura. Singapura selaku daerah pesisir mendorong aktivitas kemaritiman penduduk Singapura dengan profesi nelayan serta pedagang (Chaerullah, 2011: 11).

Letak Singapura di rute perdagangan antara Timur serta Barat sangat strategis. Saat ini, dengan ekspansi jaringan telekomunikasi yang didukung oleh sarana dan prasarana yang modern, Singapura tumbuh menjadi salah satu pusat komunikasi utama di dunia. Lalu-lintas dan pengangkutan tumbuh terus di pelabuhan Singapura, salah satu pusat distribusi serta pelabuhan tersibuk di dunia. Tiap tahun pelabuhan ini disinggahi oleh kapal-kapal dari 3 ratus dinas pelayaran dari 8 puluh negera. Sarana perbaikan serta pembuatan kapal yang melayani kebutuhan-kebutuhan pelayaran internasional telah ada. Di samping kerja teratur memperbaiki kerusakan, kelima galangan kapal utama telah banyak menanggulangi proyek-proyek modifikasi (Sasrawan, 2012: 13). Posisi Singapura telah diketahui berhasil dalam mengelola negaranya. Pelabuhan di Singapura merupakan titik pertemuan seluruh rute perdagangan negara di laut Timur dan menjadi pusat perdagangan terutama antara Calcutta dengan Hongkong. Singapura sejak dahulu memang diketahui sebagai kota pelabuhan. Rute pelayaran serta perdagangan utama antara Samudra Hindia dengan Samudra Pasifik yang dihubungkan oleh Selat Malaka, menjadikan Singapura sebagai salah satu daerah perdagangan utama di Semenanjung Malaya (Sasrawan, 2012: 5).

Dengan berperannya Semenanjung Malaya selaku titik setengah jalur antara India dan Tiongkok, kekuatan geopolitik jadi pertimbangan sungguh-sungguh. pada 1763 dimana Inggris sudah jadi kekuatan tranding Eropa yang dominan di India. Pada fase ketiga abad ke-19 Singapura telah menjadi pusat lalu-lintas di lautan Hindia. Usaha Kolonel Belanda untuk menjadikan wilayah Riau sebagai pelabuhan Hindia Navigasi kelautan bertumpu kepada angin monsoon yang dibagi ke dalam 2 angin masa; masa barat ataupun masa berlayar, serta masa timur ataupun masa sela waktu berlayar. Para pedagang menggunakan angin buat berlayar, setelah itu berlabuh buat membetulkan kapal, membuat perkampungan, dan berhubungan dengan warga setempat. Akusisi permukiman-permukiman ini serta pertumbuhan mereka berikutnya disebabkan oleh persaingan ekonomi yang intens kala perdagangan Tiongkok terus menjadi berarti (Chaerullah, 2011: 29).

Seiring waktu, jumlah orang asing dan pedagang kulit putih terus meningkat. Informasi tentang Permukiman Singapura tersebar luas, sehingga menjadi jelas bahwa tempat tersebut menjadi pemukiman. Banyak orang dari berbagai negara pindah ke Singapura. Ada yang menjadi perantara pedagang dan importir barang dagangan dari berbagai tempat. Karena itu, populasi pemukiman terus menjadi besar. Kota ini penuh sesak dengan orang-orang dari berbagai ras. Masing-masing menawarkan berbagai barang dagangan dan kemampuan. Semua orang ini tinggal di Singapura. Tidak heran jika Inggris menjadikan Singapura sebagai pusat perdagangan mereka pada abad ke-19 (Hannigan, 2012: 43).

Pada tahun 1820, setahun setelah pendudukan, tidak kurang dari 13.000 ton kapal lokal berlayar dari pelabuhan Singapura, semuanya digunakan untuk berbagai jenis perdagangan dan 
Pembangunan Singapura Selaku Pusat Perdagangan di Asia Tenggara Pada Masa Gubernur Jenderal Raffles (1819-1820)

hampir 55.000 ton kapal Eropa berlabuh di sini untuk barter atau memperoleh pasokan. Hingga tahun ketiga pendudukan, tidak ada upaya untuk memperkirakan nilai perdagangan di pulau itu. Tidak ada pelabuhan Asia dan hanya beberapa pelabuhan Eropa yang bisa menandingi keragaman perdagangan di Singapura. Kemampuan pulau-pulau teratas Inggris di Semenanjung Malaya hasil perjanjian London 1824 dengan Belanda, mengambil giliran dalam hal kehidupan sosial ekonomi Muslim Melayu (Dobbs, 2002: 42).

Perdagangan merupakan salah satu fokus perekonomian Singapura. Zona ini merupakan kekuatan yang luar biasa hanya dalam perjalanan beberapa dekade, perdagangan telah berhasil mengubah Singapura dan desa-desa nelayan menjadi negara yang makmur. Dengan perdagangan bebasnya, Singapura berdagang dengan hampir semua negara di dunia. Lokasinya strategis, serta ekonomi politiknya yang normal; semuanya mendesak pengusaha dari berbagai negara untuk mengklasifikasikan Singapura sebagai pusat distribusi berbagai produk atau layanan basis bedah ke negara lain. Transportasi serta jaringan komunikasi yang memadai, perbankan, pergudangan, dan jasa asuransi, semuanya mendukung perkembangan perdagangan dalam negeri (Chaerullah, 2011: 36).

Namun, untuk saat ini, negara bagian Singapura dinyatakan sebagai pelabuhan terbesar di dunia. Pelabuhan Singapura sering dikunjungi oleh kapal dagang. Apalagi dari situasi ini, perkembangan ekonomi untuk bidang perdagangan berkembang pesat. Perdagangan di Singapura menjadi salah satu pusat perdagangan terbesar di dunia. Hal ini didukung dengan letak Singapura yang strategis, menjadikan negara tersebut sebagai tempat transit perdagangan. Tidak heran jika Singapura dikatakan sebagai negara yang sangat maju secara ekonomi di Asia Tenggara (Mangandalaram, 1987: 42).

Singapura, dan bagian lain di Asia Tenggara, cenderung berfokus pada administrasi kolonial, pembangunan ekonomi, dan posisi elit pribumi. Lalu lintas dan transportasi terus tumbuh di pelabuhan Singapura, salah satu pusat distribusi dan pelabuhan tersibuk di dunia. Setiap tahun, pelabuhan ini dikunjungi oleh kapal dari 3 ratus jasa pelayaran dari delapan puluh negara. Banyak kegiatan ekonomi Singapura ditandai dengan banyaknya kegiatan pelabuhan sungai oleh tongkang barang. Fasilitas revisi dan pembuatan kapal yang melayani kebutuhan navigasi internasional sudah ada. Selain pekerjaan perbaikan rutin, lima galangan kapal besar sedang menangani proyek modifikasi. Revisi tertentu juga dapat dicoba di galangan kapal dengan dimensi yang lebih panjang dan lebih kecil, atau langsung di pelabuhan (Vlekke, 2008: $30)$.

Singapura memiliki salah satu pelabuhan tersibuk di dunia dan merupakan pusat devisa terbesar keempat di dunia setelah London, New York dan Tokyo. Bank Dunia menempatkan Singapura sebagai pusat logistik top dunia. Ekonomi Singapura terdaftar di antara 10 negara paling terbuka, kompetitif, dan inovatif di dunia. Dianggap sebagai negara paling ramah bisnis di dunia, ratusan ribu ekspatriat asing bekerja di Singapura di berbagai industri multinasional. Ada juga ratusan ribu pekerja manual asing. Letak Singapura yang sangat strategis membuat zona perdagangan dan jasa berkembang sangat pesat, terutama di kawasan Asia Tenggara. Singapura menyediakan berbagai fasilitas penerbangan dan pelabuhan laut secara lengkap, 
Pembangunan Singapura Selaku Pusat Perdagangan di Asia Tenggara Pada Masa Gubernur Jenderal Raffles (1819-1820)

menjadikannya tempat persinggahan sementara (transit) kapal atau pesawat dari berbagai maskapai yang ingin melanjutkan perjalanannya. Kondisi politik dan keamanan yang normal menjadikan Singapura sebagai tujuan investasi, terutama bagi negara-negara Barat yang ingin memperluas pasarnya di Asia (Sasrawan, 2012: 7).

\section{Kesimpulan}

Pembangunan Singapura sebagai pusat perdagangan di Asia Tenggara pada masa Gubernur Jenderal Raffles (1819-1820) dapat dijadikan cermin yang jelas bahwa Singapura selaku pusat perdagangan yang sangat maju hingga saat ini merupakan kejelian dan pikiranpikiran briliyan tentang masa depan oleh seorang Raffles. Singapura atau tadinya yang diketahui sebagai Tumasik, ialah salah satu bagian dari gugusan pulau di bagian selatan Selat Malaka yang tidak pernah terpikirkan akan menjadi kota pelabuhan penting pada abad ke-21. Pada abad ke-14 Singapura hanya berupa wilayah rawa-rawa dengan pesisir perairan yang luas dan dengan kepadatan penduduk sangat rendah. Singapura saat sebelum datangnya Raffles masih berbentuk hutan bakau yang menutupi segala pulau, belum terdapat rumah satu juga di pulau ini.

Raffles tidaklah orang yang berkarakter hebat, tetapi ia lumayan bijaksana buat lebih memilah reputasi dalam sejarah daripada pemasukan material sesaat. Buat membangun reputasi itu Raffles bekerja seumur hidupnya, mula-mula dengan melayani negarawan-negarawan utama, setelah itu melalui tulisan-tulisannya, Raffles menjadi legenda historis pada masa kepemimpinan administrasinya di Jawa. Keputusannya dengan kebijakan perluasan yang berani membuat Raffles menggapai keberhasilan terbesarnya mendirikan Singapura. Letak Singapura di rute perdagangan antara Timur serta Barat sangat strategis. Saat ini, dengan ekspansi jaringan telekomunikasi, serta didukung oleh sarana yang modern, Singapura tumbuh jadi salah satu pusat komunikasi utama di dunia. Lalu-lintas serta pengangkutan terus tumbuh di pelabuhan Singapura, menjadi salah satu pusat distribusi serta pelabuhan tersibuk di dunia. Singapura layak menjadi contoh Kota Pelabuhan yang berhasil bergerak maju di abad ke-21 ini. Banyak hal yang pantas dicontoh dari Singapura., pengembangan kawasan industri serta pelabuhan yang dahulunya tercemar jadi area yang bersih dengan kondominium ekslusif serta modern merupakan salah satu keberhasilan dalam pembangunan Singapura modern.

\section{Daftar Rujukan}

Amin, S. (2018). Islam Dan Keharmonian Kaum Di Singapura. Ri'ayah: Jurnal Sosial dan Keagamaan, 3(01), 69-82.

Bastin, John. (2011). Singapura Tempoe Doeloe. Depok: Komunitas Bambu.

Chaerullah, I. (2011). Aktivitas Pelayaran Dan Perdagangan Masyarakat Muslim Melayu Singapura Tahun 1800-1824. Skripsi. Sekolah Sarjana, Universitas Islam Negeri Syarif Hidayatullah, Jakarta

Dobbs, Stephan. (2002). The Singapura River: A Social History 1819-2000. Singapura: Singapure University Press.

Gottschalk, Louis. (1985). Mengerti Sejarah. Jakarta: Universitas Indonesia Pers.

Hannigan, Tim. (2012). Raffles dan Infansi Inggris ke Jawa. Jakarta: Gramedia. 
Pembangunan Singapura Selaku Pusat Perdagangan di Asia Tenggara Pada Masa Gubernur Jenderal Raffles (1819-1820)

Ibrahim, Zuraidah dkk. (1953). Orang Islam di Singapura. Singapore: Majlis Agama Islam Singapura.

Idris, H. (1997). Pulau Singapura, 1819-1930: Peranan Pulau-pulau lain yang Terpinggir di dalam Sejarahnya. Jati-Journal of Southeast Asian Studies, 3, 63-83.

Kennedy, J. (1962). A History of Malaya A.D. 1400-1959. London: MacMillan \& CO LTD.

Mangandalaram, Syahbuddin. (1987). Mengenal dari Dekat Malaysia Negara Tetangga Kita Dalam ASEAN. Bandung: Remadja Karya.

Mills, L.A., "British Malaya 1824-67; Singapura 1819-1826”, Journal of the Malayan Branch of the Royal Asiatic Society, 8(3\&4).

Phillippe, Regnier. (1991) Singapura City-State in South-East Asia. Honolulu: University of Hawaii Press.

Pratomo, Julia. (2018). Pesona Raffles Landing Site Sebagai Destinasi Wisata di Singapura. Yogyakarta: Sekolah Tinggi Pariwisata Ambarrukmo.

Saefullah, A. (2016). Tumasik: Sejarah Awal Islam di Singapura (1200-1511 M). Jurnal Lektur Keagamaan, 14(2), 419-456.

Sasrawan, Hedi, "Letak Geografis Singapura", http://hedisasrawan.blogspot.com/2013/03/letak-geografis-singapura.html, Diunduh 21 May 2021, pukul 14.05 WIB.

Siryayasa, I. N., \& Yasin, M. S. (2019). Pelabuhan, Perdagangan dan Ekonomi: Makassar dalam Kurun Niaga di Asia Tenggara. Fajar Historia: Jurnal Ilmu Sejarah dan Pendidikan, 3(2), 88-97.

Sjamsuddin, Helius. (2007). Metodologi Sejarah. Yogyakarta: Ombak.

Syah, Djalinus. (1985). Mengenal ASEAN dan Negara-negara Anggotanya. Jakarta: PT.Kreasi Jaya Utama.

Trocki, Carl. A. (1979). Prince of Pirates: The Temenggongs and The Temenggongs and The Development of Johore and Singapura 1784-1885. Singapore: Singapura University Press.

Vlekke, Bernard. H. M. (2008). Nusantara Sejarah Indonesia. Jakarta: Gramedia. 